\title{
Effect of type and concentration of substrate on power generation in a dual chambered microbial fuel cell
}

\author{
A.A. Ghoreyshi ${ }^{1, *}$, T.Jafary ${ }^{1}$, G.D. Najafpour ${ }^{1}$, F.Haghparast ${ }^{1}$ \\ ${ }^{1}$ Chemical Engineering Department, Babol University of Technology, Babol, Iran \\ *Corresponding author. Tel: 00981113234204, Fax: 00981113234204,E-mail: aa_ghoreyshi@nit.ac.ir
}

\begin{abstract}
Microbial fuel cell, as a new technology for energy generation, has gained a lot of attention in converting a wide range of organic and inorganic substrates to bioelectricity in recent years. Substrate as the fuel of MFCs has an effective role on the performance of MFCs. To investigate the effect of type and concentration of substrate on the MFC performance, glucose and date syrup were examined over a concentration range of 2-20 g. $\mathrm{l}^{-1}$. Date syrup or any waste of date could be used as a natural substrate while glucose is considered as a synthetic carbon source. In this research a two-rectangular chambered MFC separated by a Nafion 112 proton exchange membrane, was constructed. The anodic compartment was inoculated by saccharomyces cerevisiae as biocatalyst. $200 \mu \mathrm{mol}^{-l^{-1}}$ of neutral red as the anodic mediator and $300 \mu \mathrm{mol}^{-1} \mathrm{I}^{-1}$ of potassium ferricyanide as oxidizer were added to anode and cathode chambers, respectively. The results has shown that $3 \mathrm{~g}^{-1} \mathrm{l}^{-1}$ date syrupfed- MFC had the highest power density, $51.95 \mathrm{~mW} \cdot \mathrm{m}^{-2}$ (normalized to the geometric area of the anodic membrane, which was $9 \mathrm{~cm}^{2}$ ), corresponding to a current density of $109.0384 \mathrm{~mA} \cdot \mathrm{m}^{-2}$ and a MFC voltage of $967 \mathrm{mV}$.
\end{abstract}

Keywords: Microbial fuel cell, Substrate, Glucose, Date syrup, Power density.

\section{Introduction}

The microbial fuel cells convert the chemical content in organic and inorganic compounds to electricity via catalytic activity of microorganisms as the biocatalyst. Oxidation of substrate in anode chamber by microorganisms results in proton and electron production. Protons are transferred to cathode chamber through proton exchange membrane [1-3] . Depending on the type of electron transfer mechanisms, MFCs are categorized to two main groups, i.e. MFCs using mediator and mediator less MFCs [4].

Proton exchange system [5], electrode type and distance [6], temperature [7], $\mathrm{pH}$ [8], inoculums [9] and substrate $[10,11]$ as the main effective parameters on MFCs performance were investigated by many researchers. The substrate, as a key parameter, influences the integral composition of the bacterial community in the anode biofilm, and the MFC performance including the power density (PD) and Coulombic efficiency (CE) [12]. MFCs have been solely considered as a bioelectricity generation method, until different wastewaters were utilized as the fuel in anode chamber for the wastewater treatment [13]. Wide varieties of substrates ranging from pure compounds to complex mixture of organic matters present in wastewater have been used in MFCs as the carbon source for bioelectricity generation as well as wastewater treatment purposes. Acetate [14] and glucose [15] as the most common substrates, sucrose [16], xylose [17] and varios types of wastewater like synthetic [18], domestic [19], brewery [20], swine [21] and paper recycling wastewater [22] with different concentrations have been studied by many researchers. But it is difficult from literature to compare MFCs performances, due to different operating conditions such as surface area, type of electrodes and different microorganisms used. The main purpose of this article was to investigate the effect of two types of substrates, i.e. glucose and date syrup, as well as their concentration on the MFC electrical performance in a dual chambered fuel cell. Date is one of the main products of desert regions and its application as a substrate for MFCs in environmental biosensors in remote areas could be considered. A comparison was made by 
the measurement of polarization curve under various concentrations for both types of substrates. Different concentrations ranging from 2- 20 g. $l^{-1}$ were chosen, while all other conditions kept constant.

\section{Methodology}

Saccharomyces cerevisiae PTCC 5269 was supplied by Iranian Research Organization for Science and Technology, Tehran, Iran. The microorganisms were grown in an anaerobic jar. The general medium for seed culture of both, Glucose-fed and date syrup-fed MFCs, consisted of yeast extract, $\mathrm{NH}_{4} \mathrm{Cl}, \mathrm{NaH}_{2} \mathrm{PO}_{4}, \mathrm{MgSO}_{4}$ and $\mathrm{MnSo}_{4}$ : 3, 0.2, 0.6, 0.2 and 0.05 g. $l^{-1}$, respectively. Glucose and date syrup as the carbon sources were added to this medium in a range 1-20 g. l $^{-1}$. Due to high concentration of date syrup, date syrup was pretreated with different methods to break all its complex mixture to glucose. It was diluted, hydrolyzed with hydrochloric acid and then autoclaved for several times till getting constant sugar content. These processes convert all its sugar content to glucose. The medium then was sterilized, autoclaved at $121^{\circ} \mathrm{C}$ and 15 psig for $20 \mathrm{~min}$.

The medium $\mathrm{pH}$ was initially adjusted to 6.5 and the inoculum was introduced into the media at ambient temperature. The inoculated cultures were incubated at $30^{\circ} \mathrm{C}$. The bacteria were fully grown for the duration of 24 hours in $100 \mathrm{ml}$ flux without any agitation. Substrate consumption was calculated based on determination of the remained sugars in the culture. All chemicals and reagents used for the experiments were analytical grades and supplied by Merck (Germany). The pH meter, HANA 211(Romania) model glass-electrode was employed for the $\mathrm{pH}$ measurements of samples in the aqueous phase. The initial $\mathrm{pH}$ of the working solutions was adjusted by addition of dilute $\mathrm{HNO}_{3}$ or $0.1 \mathrm{M} \mathrm{NaOH}$ solutions. DNS reagent was developed to detect and measure substrate consumption using colorimetric method [23] and cell growth was also monitored by optical density using spectrophotometer (Unico, USA).

The fabricated cells in the laboratory scale were made of Plexiglas material. The volume of each chamber (anode and cathode chambers) was $800 \mathrm{ml}$ with working volume of $600 \mathrm{ml}$ (75\% of total volume). The sample port was provided for the anode chamber, wire point inputs and inlet port. The selected electrodes in MFC were graphite felt in size of $50 \times 35 \times 2$ $\mathrm{mm}$. Proton exchange membrane (PEM; NAFION 112, Sigma-Aldrich) was used to separate two compartments. The Nafion area separated the chambers was $3.79 \mathrm{~cm}^{2}$. Nafion as a proton exchange membrane was subjected to a course pretreatment to take off any impurities that was boiling the film for $1 \mathrm{~h}$ in $3 \% \mathrm{H}_{2} \mathrm{O}_{2}$, washed with deionized water, $0.5 \mathrm{M} \mathrm{H}_{2} \mathrm{SO}_{4}$, and then washed with deionized water. The anode and cathode compartments were filled by deionized water when the biological fuel cell was not in use to maintain membrane for good conductivity. Natural Red and Ferricyanide were supplied by Merck (Germany). These chemicals in optimum concentrations $\left(200 \mu \mathrm{mol}^{-\mathrm{l}^{-1}} \& 300 \mu \mathrm{mol} . \mathrm{l}^{-1}\right)$ were used as mediators in anode and cathode of MFC, respectively.

S.cerevisiae used as a biocatalyst in microbial fuel cell for production of bioelectricity from carbohydrate source. This microorganism was grown under anaerobic condition in biofuel cell. Fixed incubation time and enriched media was used. The obtained data has shown that S.cerevisiae had good ability for consumption of substrate at anaerobic condition

The schematic diagram and illustration of the fabricated experimental set up with auxiliary equipments are shown in Fig. 1. 

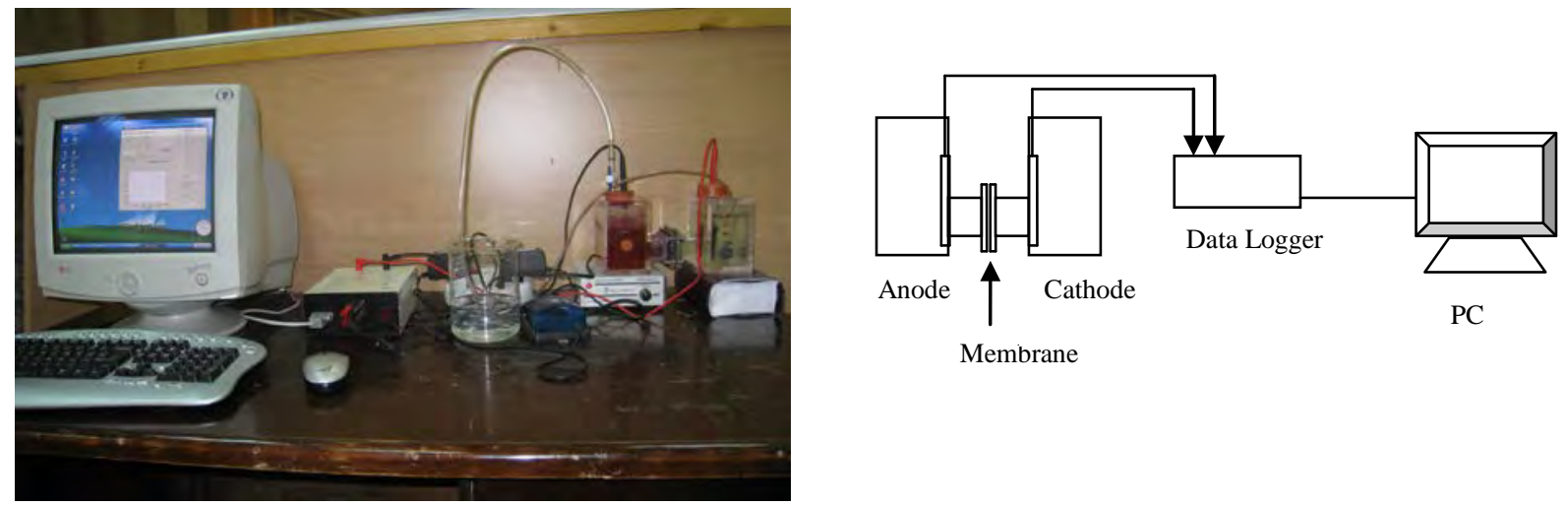

Fig. 1. The schematic diagram and illustration of the fabricated experimental set up with auxiliary equipments

\section{Results and discussion}

As the MFC were inoculated with S.cerevisiae, the voltage was continuously monitored by a data acquisition system to reach the constant open circuit voltage (OCV). It took 42, 57, 67, 65, 58, 48 and 30 hours for glucose with concentration of 1, 3, 5, 7, 10, 20 and 30 g.l $^{-1}$ to reach constant voltage of $922,957,970,955,920,800 \mathrm{mV}$ respectively, These results were 64 , $67,72,68,64,52$ and 40 hours for the same concentrations of date syrup with the constant OCV of 988, 985, 948, 922, 916, $656 \mathrm{mV}$ respectively. The results indicated that an increase in the substrate concentration increased the time needed to reach constant OCV at low concentration of 1-5 g.l ${ }^{-1}$ for glucose and $1-3$ g. $l^{-1}$ for date syrup.

Polarization curves were recorded by the data acquisition system after the mentioned time duration when the constant OCV was achieved. Fig. 2 shows polarization curves of the MFC at the glucose concentration range of $1-20 \mathrm{~g}^{-1} \mathrm{l}^{-1}$. As the glucose concentration increased from 1 to $5 \mathrm{~g} . \mathrm{l}^{-1}$, power and current density gradually increased. However when the glucose concentration increased from 7 to $20 \mathrm{~g} . \mathrm{l}^{-1}$, it was observed that the power and current density were considerably decreased. That was because the most of glucose remained unconsumed at high concentrations. The increase in time duration to reach constant OCV at low concentrations of 1-5 g..$^{-1}$ for glucose and 1-3 g. $\mathrm{l}^{-1}$ for date syrup, and subsequently the decrease at higher concentrations, 7-20 g. $\mathrm{l}^{-1}$ for glucose and 5-20 g. $\mathrm{l}^{-1}$ for date syrup, can be also attributed to the substrate inhibition effect. Indeed, all carbon sources available in the substrate solution at low concentrations were consumed resulted in longer time for attaining constant OCV. However as the substrate concentration increased, the constant OCV was achieved earlier with lower outputs, due to limitation in consuming carbon content in the substrate at higher concentration by microorganisms. 

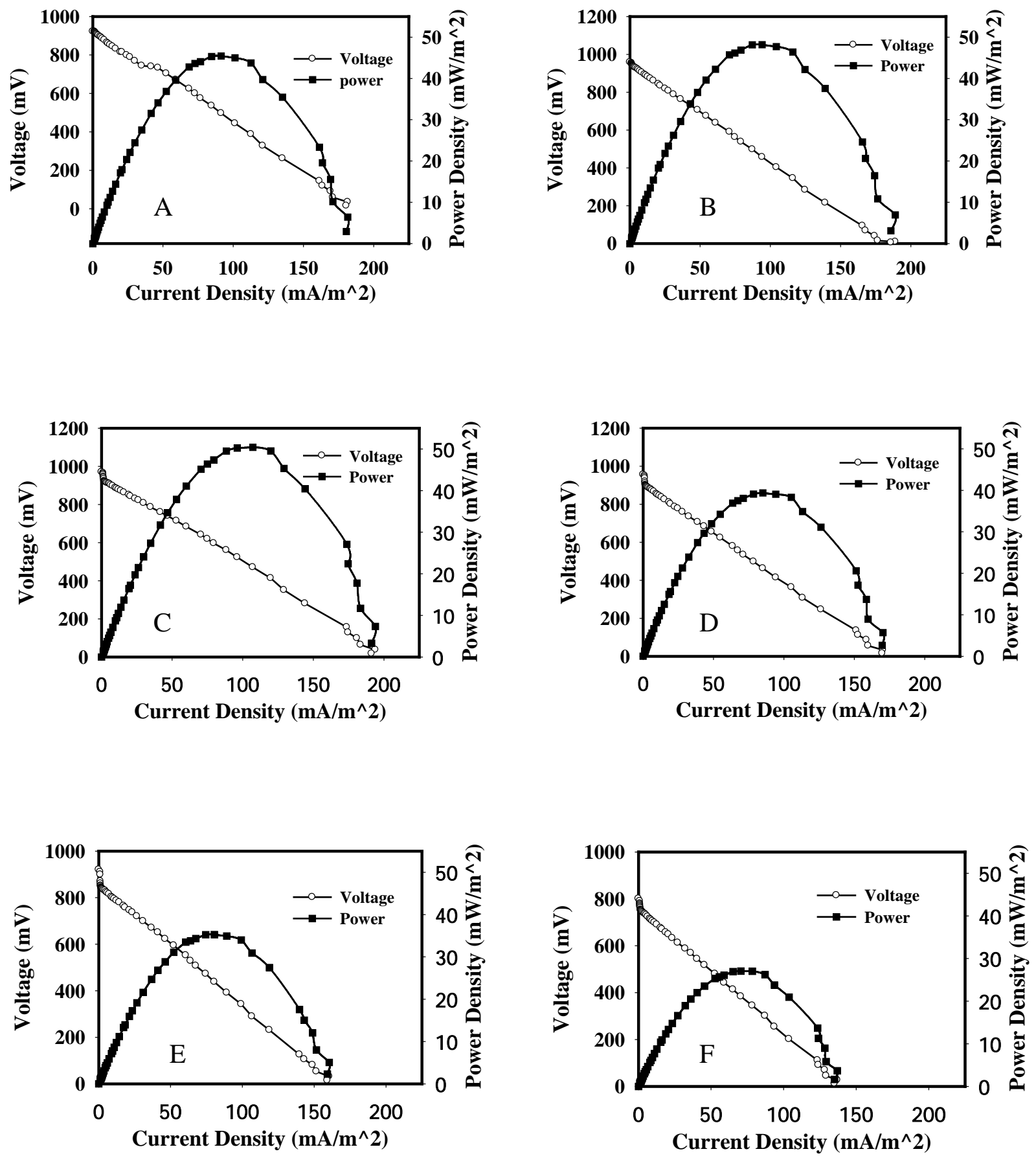

Fig. 1. Effect of different glucose concentrations on polarization curves

A) $1 \mathrm{~g} . \mathrm{l}^{-1}$, B) $2 \mathrm{~g} . \mathrm{l}^{-1}$, C) $5 \mathrm{~g} . \mathrm{l}^{-1}$, D) $7 \mathrm{g.l} \mathrm{l}^{-1}$, E) $10 \mathrm{g.l} \mathrm{l}^{-1}$, F) $20 \mathrm{~g} . \mathrm{l}^{-1}$

Fig. 3 shows polarization curves for the date syrup at the same concentration range. Comparing the results shown in Figure 2 and 3, the best results were achieved at the concentration 3 g..$^{-1}$ of date syrup with the maximum power $53.7031 \mathrm{~mW} . \mathrm{m}^{-2}$ and current density $110.86 \mathrm{~mA} . \mathrm{m}^{-2}$.These results were followed by $5 \mathrm{~g} . \mathrm{l}^{-1}$ of glucose $\left(50.41 \mathrm{~mW} \cdot \mathrm{m}^{-2}\right.$, $107.16 \mathrm{~mA} \cdot \mathrm{m}^{-2}$ ), 5 g. $\mathrm{l}^{-1}$ of date syrup (49.51 mW.m ${ }^{-2}, 195.19 \mathrm{~mA} \cdot \mathrm{m}^{-2}$ ) , 3 g. $\mathrm{l}^{-1}$ of glucose (48.23 mW.m $\left.\mathrm{m}^{-2}, 94.16 \mathrm{~mA} . \mathrm{m}^{-2}\right)$ and $1 \mathrm{~g} . \mathrm{l}^{-1}$ of date syrup $\left(47.36 \mathrm{~mW} . \mathrm{m}^{-2}, 104.12 \mathrm{~mA} . \mathrm{m}^{-2}\right)$. 

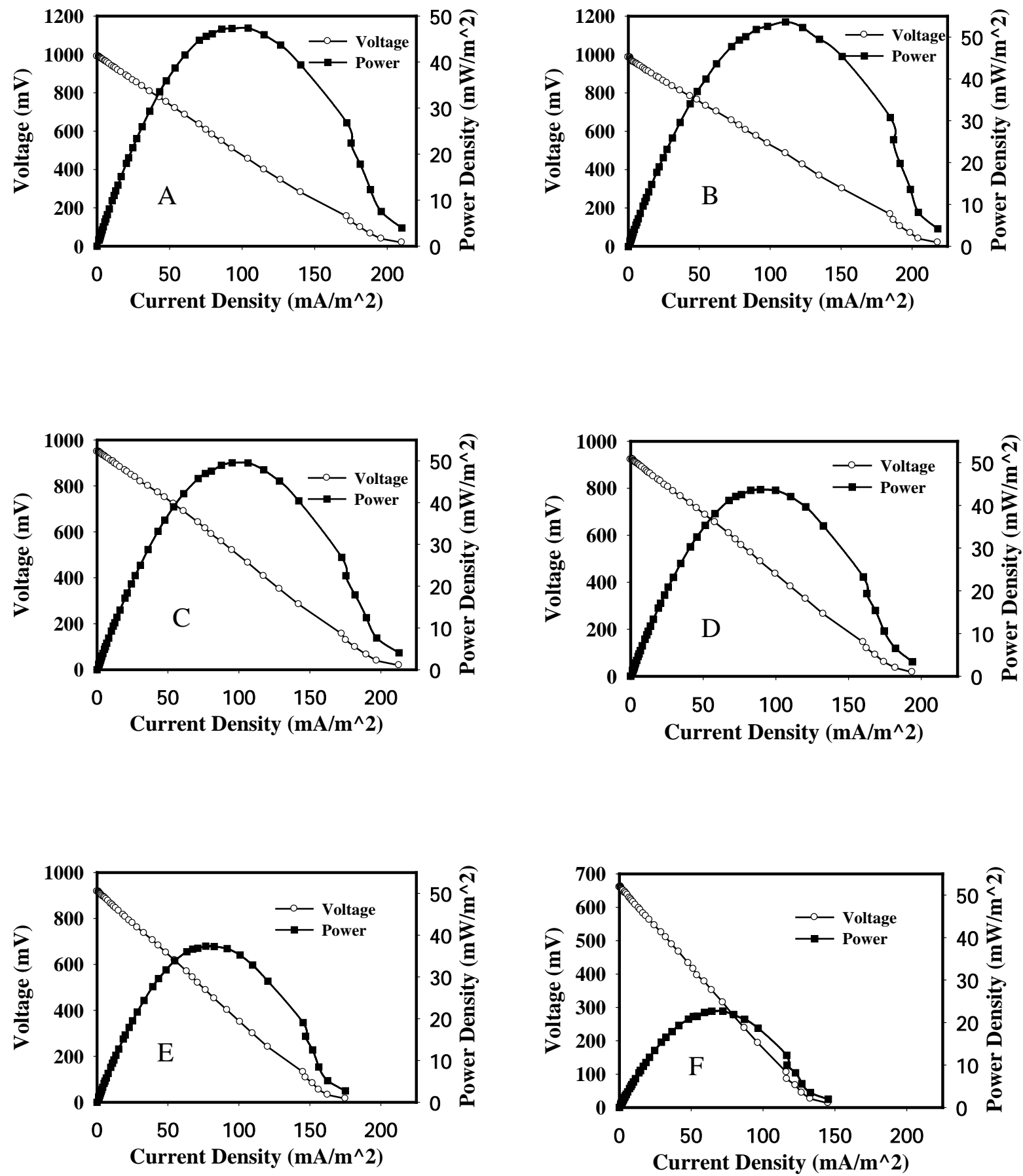

Fig. 3. Effect of different date syrup concentrations on polarization curves

$$
\left.1 \mathrm{~g} . \mathrm{l}^{-1}, \text { B) } 2 \mathrm{~g} . \mathrm{l}^{-1}, \mathrm{C)} 5 \mathrm{~g} . \mathrm{l}^{-1}, \mathrm{D}\right) 7 \mathrm{~g} . \mathrm{l}^{-1}, \text { E) } 10 \mathrm{~g} . \mathrm{l}^{-1}, \text { F) } 20 \mathrm{~g} . \mathrm{l}^{-1}
$$

Fig. 4 compares the power and current output for the two types of substrates used in this study at their optimum concentration. The Figure indicates a superior electrical performance for the date syrup compared to the glucose. 


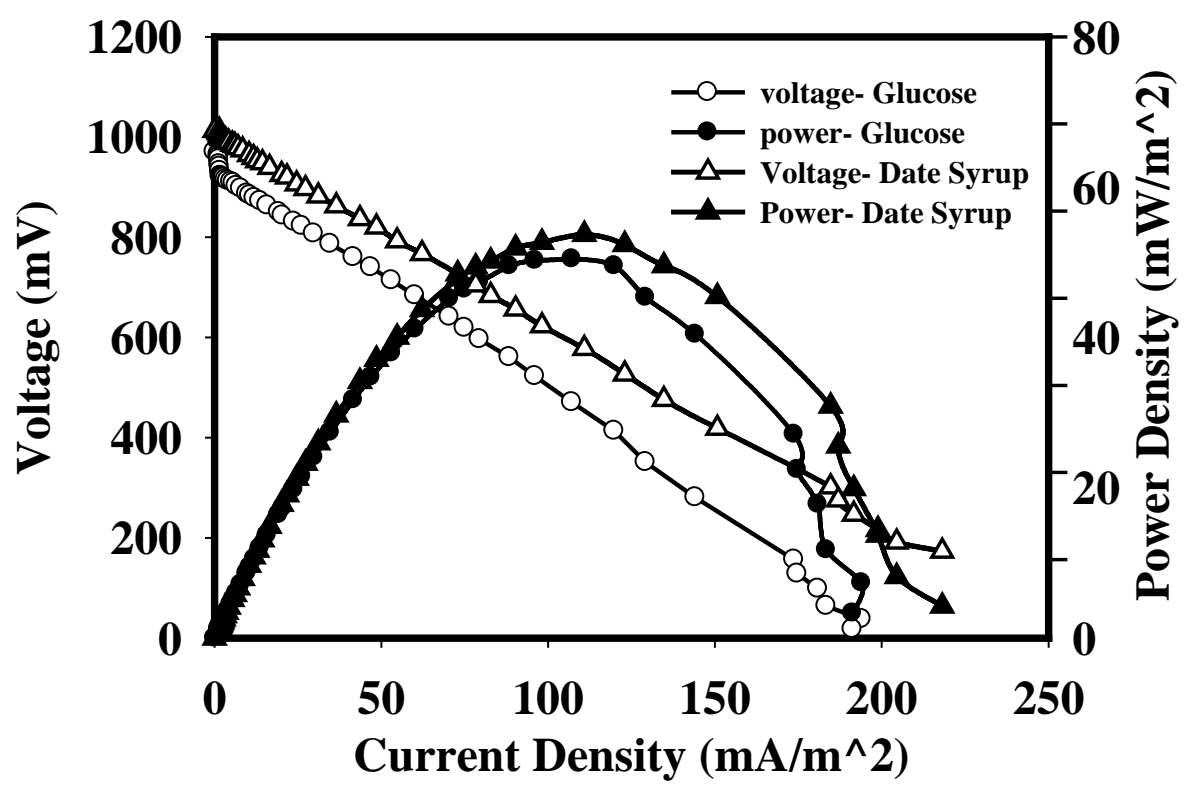

Fig. 4. Comparison of the MFC electrical performance working with glucose and date syrup as substrate at optimum concentration

\section{Conclusions}

In this study the effect of substrate type and concentration on the performance of microbial fuel cells was investigated. The glucose and date syrup were utilized as the carbon source for the production of electrical energy by means of Saccharomyces cerevisiae as the biocatalyst. Several concentrations of glucose and date syrup at the range of 1-20 g. $\mathrm{l}^{-1}$ were experimented in a two-chambered fabricated MFC. The results revealed that the optimum concentration with the highest electrical performance were 3 g.l $^{-1}$ for date syrup and 5 g.l $\mathrm{l}^{-1}$ for glucose. Comparing the two types of substrates used in this study, date syrup has shown a superior electrical performance. The best results was achieved using the date syrup at optimum concentration of 3 g.l $^{-1}$ with the maximum power $53.7031 \mathrm{~mW} \cdot \mathrm{m}^{-2}$ and current density 110.86 $\mathrm{mA} \cdot \mathrm{m}^{-2}$. The results also indicated that the substrate inhibition effect may have a significant role in the performance of MFC at high concentration of glucose and date syrup. 


\section{References}

[1] Z. D. Liu and H. R. Li, Effects of bio-and abio-factors on electricity production in a mediatorless microbial fuel cell, Biochemical Engineering Journal 36, 2007, pp. 209214.

[2] M. S. Kim and Y. Lee, Optimization of culture conditions and electricity generation using Geobacter sulfurreducens in a dual-chambered microbial fuel-cell, International Journal of Hydrogen Energy 35, 2010, pp. 13028-13034.

[3] A. Larrosa, L. J. Lozano, K. P. Katuri, I. Head, K. Scott, and C. Godinez, On the repeatability and reproducibility of experimental two-chambered microbial fuel cells, Fuel 88, 2009, pp. 1852-1857.

[4] X. Tang, Z. Du, and H. Li, Anodic Electron Shuttle Mechanism Based on 1-Hydroxy4-Aminoanthraquinone in Microbial Fuel Cells, Electrochemistry Communications 12, 2010, pp. 1140-1143.

[5] K. Chae, M. Choi, F. Ajayi, W. Park, I. Chang, and I. Kim, Mass Transport through a Proton Exchange Membrane (Nafion) in Microbial Fuel Cellst, Energy \& Fuels 22, 2007, pp. 169-176.

[6] F. Li, Y. Sharma, Y. Lei, B. Li, and Q. Zhou, Microbial Fuel Cells: The Effects of Configurations, Electrolyte Solutions, and Electrode Materials on Power Generation, Applied biochemistry and biotechnology 160, 2010, pp. 168-181.

[7] A. Larrosa-Guerrero, K. Scott, I. M. Head, F. Mateo, A. Ginesta, and C. Godinez, Effect of temperature on the performance of microbial fuel cells, Fuel 2010, pp.

[8] Z. He, Y. Huang, A. K. Manohar, and F. Mansfeld, Effect of electrolyte $\mathrm{pH}$ on the rate of the anodic and cathodic reactions in an air-cathode microbial fuel cell, Bioelectrochemistry 74, 2008, pp. 78-82.

[9] I. Ieropoulos, J. Winfield, and J. Greenman, Effects of flow-rate, inoculum and time on the internal resistance of microbial fuel cells, Bioresource technology 101, 2010, pp. 3520-3525.

[10] K. Chae, M. Choi, J. Lee, K. Kim, and I. Kim, Effect of different substrates on the performance, bacterial diversity, and bacterial viability in microbial fuel cells, Bioresource technology 100, 2009, pp. 3518-3525.

[11] A. Thygesen, F. W. Poulsen, B. Min, I. Angelidaki, and A. B. Thomsen, The effect of different substrates and humic acid on power generation in microbial fuel cell operation, Bioresource technology 100, 2009, pp. 1186-1191.

[12] D. Pant, G. Van Bogaert, L. Diels, and K. Vanbroekhoven, A review of the substrates used in microbial fuel cells (MFCs) for sustainable energy production, Bioresource technology 101, 2010, pp. 1533-1543.

[13] W. Habermann and E. Pommer, Biological fuel cells with sulphide storage capacity, Applied microbiology and biotechnology 35, 1991, pp. 128-133.

[14] H. Liu, S. Cheng, and B. E. Logan, Production of electricity from acetate or butyrate using a single-chamber microbial fuel cell, Environ. Sci. Technol 39, 2005, pp. 658662.

[15] S. Chaudhuri and D. Lovley, Electricity generation by direct oxidation of glucose in mediatorless microbial fuel cells, Nature Biotechnology 21, 2003, pp. 1229-1232.

[16] M. Behera and M. Ghangrekar, Performance of microbial fuel cell in response to change in sludge loading rate at different anodic feed $\mathrm{pH}$, Bioresource technology 100, 2009, pp. 5114-5121.

[17] L. Huang, R. J. Zeng, and I. Angelidaki, Electricity production from xylose using a mediator-less microbial fuel cell, Bioresource technology 99, 2008, pp. 4178-4184.

[18] S. Venkata Mohan, G. Mohanakrishna, B. P. Reddy, R. Saravanan, and P. N. Sarma, Bioelectricity generation from chemical wastewater treatment in mediatorless (anode) 
microbial fuel cell (MFC) using selectively enriched hydrogen producing mixed culture under acidophilic microenvironment, Biochemical Engineering Journal 39, 2008, pp. 121-130.

[19] X. Wang, Y. Feng, N. Ren, H. Wang, H. Lee, N. Li, and Q. Zhao, Accelerated start-up of two-chambered microbial fuel cells: Effect of anodic positive poised potential, Electrochimica Acta 54, 2009, pp. 1109-1114.

[20] Y. Feng, X. Wang, B. Logan, and H. Lee, Brewery wastewater treatment using aircathode microbial fuel cells, Applied microbiology and biotechnology 78, 2008, pp. 873-880.

[21] B. Min, J. R. Kim, S. E. Oh, J. M. Regan, and B. E. Logan, Electricity generation from swine wastewater using microbial fuel cells, Water Research 39, 2005, pp. 4961-4968.

[22] L. Huang and B. E. Logan, Electricity generation and treatment of paper recycling wastewater using a microbial fuel cell, Applied microbiology and biotechnology 80, 2008, pp. 349-355.

[23] G. Chamberlin and G. Shute, Colorimetric chemical analytical methods, 1974 